Василь Осьодло, доктор психологічних наук, професор Національний університет оборони України імені Івана Черняховського, м. Київ ORCID ID 0000-0003-2893-4721

Олег Рибчук, доктор філософії

Національний університет оборони України імені Івана Черняховського, м. Київ ORCID ID 0000-0003-3966-8326

Тетяна Ворона, Національний університет оборони України імені Івана Черняховського, м. Київ ORCID ID 0000-0001-5544-3341

DOI: $10.33099 / 2617-1775 / 2020-02 / 232-242$

\title{
НАУКОВІ ПІДХОДИ ДО УПРАВЛІННЯ ОСВІТНІМ ПРОЦЕСОМ У ВИЩИХ ВІЙСЬКОВИХ НАВЧАЛЬНИХ ЗАКЛАДАХ
}

Стаття присвячена дослідженню наукових підходів до управління освітнім процесом у вищих військових навчальних закладах. На основі аналізу сучасних наукових розвідок визначено закономірності та тендениії розвиту освітнього процесу в умовах трансформаційних процесів. Обтрунтовано філософські та методологічні детермінанти нової освітньої парадигми, відповідно до якої система управління вищим військовим навчальним закладом, як система відкритого типу, на основі виокремлення найкращих освітніх практик та прийняття їх за стандарти освітньої діяльності формує нову ділову організаційну культуру. Обтрунтовано завдання сучасного освітнього менеджменту вищих військових навчальних закладів, щзо полягає у визначенні соціально значущих цілей освітньої діяльності, професіоналізащії науково-педагогічних працівників шляхом розвитку їхнього особистісного потенціалу, забезпеченні внутрішніх та зовнішніх комунікацій та розподілі ресурсів відповідно до освітніх пріоритетів.

Ключові слова: управління; освіта; розвиток; навчальний заклад; якість.

Постановка проблеми. Від розвитку освіти залежить розвиток сучасної української держави, успішне формування та трансформація громадянського суспільства на засадах гуманізму, верховенства права та свободи особистості. В основу сучасної освітньої парадигми закладено цінність людського існування, свобода і суверенність прав кожної особистості та іiі гідність, розвиток самодостатності особистості, істотними рисами якої $є$ здатність приймати самостійні відповідальні рішення й діяти творчо, потреба постійного підвищення професійного рівня, громадянська позиція. Розвиток освіти може відбуватися й сам по собі, проте щоб досягнути бажаного ефекту, освітнім процесом слід управляти і вдосконалювати його в управлінських процесах.

Для ефективного управління освітою важливо знати об'єктивні закономірності ії функціонування та розвитку. Управління на основі емпіричного досвіду та прагматичного підходу може бути успішним на короткому відрізку часу. Досягнення стратегічних цілей розвитку освіти можливе лише за умови здійснення управління освітнім процесом на наукових засадах. 
Наукові пошуки в галузі управління освітою й військовою, зокрема, значно активізувалися на початку XXI століття, коли у науковий обіг запроваджено поняття "менеджмент", "менеджмент освіти", "педагогічний менеджмент", “кадровий менеджмент", “управлінська компетентність” тощо. Переосмислення теорії управління освітньою організацією, поява нових управлінських функцій та функціональних обов'язків зумовлює й нові вимоги до управління закладами вищої освіти в сучасних умовах.

Аналіз останніх досліджень. Проблему управління закладами вищої освіти досліджують чимало вчених (Л. Даниленко, Л. Карамушка, Е. Коротков, В. Крижков, О. Мармаз, І. Толок, Є. Хриков та інші). Автори розглядають різні аспекти управлінської діяльності в освітній сфері, зокрема методологічні та наукові засади освітнього менеджменту, управління інноваційними процесами в освіті, вимоги до забезпечення якості підготовки фахівців та інші.

Окремі аспекти сучасного освітнього менеджменту висвітлені у дослідженні I. Кушніра. Зокрема вчений визначає дві групи чинників (екзогенні та ендогенні), які обумовлюють та забезпечують розвиток управління в освіті [1, с. 29]. Також визначає основні завдання освітнього менеджменту. Однак, окреслені автором завдання, на нашу думку, не повною мірою відповідають цілям діяльності закладу освіти. Реалізація наведених завдань не гарантуватиме якості освіти ії здобувачів, оскільки управлінська діяльність не може зводитися до формування лише “...цифрової компетентності всіх учасників освітнього процесу” та спрямовуватися виключно на “...забезпечення експериментальної діяльності закладу освіти...” [1, с. 29]. Також поза увагою дослідника залишаються шляхи та способи реалізації окреслених завдань в управлінні освітнім закладом.

Особливе значення у сучасних дослідженнях присвячених управлінню закладами вищої освіти відводиться проблемі моніторингу якості підготовки фахівців. Наявність та цілісність системи освітнього моніторингу розглядається як детермінанта ефективного управління освітнім процесом, що забезпечує зворотні зв'язки та сприяє ухваленню необхідних управлінських рішень. Вчені класифікують моніторинг у системі вищої військової освіти відповідно до його об'єкту та виокремлюють моніторинг якості вищої освіти, моніторинг освітньої діяльності ВВНЗ та моніторинг якості підготовки військових фахівців [2, с. 18]. Водночас моніторинг якості підготовки військових фахівців розглядається як складова системи управління якістю вищої освіти та освітньої діяльності, що формується на основі систематичного збору, обробки, аналізу, оцінювання, зберігання та оприлюднення інформації про стан освітнього процесу і його забезпечення з метою визначення відповідності отриманих результатів навчання освітнім стандартам та постійного удосконалення освітньої діяльності ВВНЗ [2, с. 18-19]. Авторами також розкрито методологічні засади та прикладні аспекти реалізації завдань моніторингу у процесі управління вищим військовим навчальним закладом [2].

Важливою умовою обгрунтування підходів до управління освітніми закладами є врахування сучасного контексту. Як вже зазначалося раніше [3], сучасний контекст визначається особливостями функціонування та розвитку 
інформаційного суспільства - глобалізаційними процесами та інформаційними взаємодіями. Відтак, провідним завданням для системи управління ВВНЗ стає налагодження внутрішніх та зовнішніх комунікацій для своєчасного та адекватного реагування на актуальні виклики.

За даними Національного інституту стратегічних досліджень “Технологічний прогрес у поєднанні з демографічними змінами призведе до розвитку людських ресурсів, покращення здатності керувати та діяти в усіх сферах, включаючи стратегічний, оперативний та тактичний рівні, та на різних територіях" [4]. Вищі військові навчальні заклади мають стати осередками новітніх наукових розробок, розвитку та впровадження проривних технологій у сфері безпеки та оборони, міжнародного співробітництва в галузі науки.

Також дослідники відмічають, що в сучасних умовах розвитку суспільства акцент освітньої діяльності зміщується 3 передачі накопиченої та узагальненої наукової інформації від викладачів до здобувачів освіти на залучення до участі в наукових дослідженнях, забезпечення доступу до наукової інформації та консультативне супроводження у процесі іiї засвоєння.

Аналіз наукових розвідок засвідчив, що відкритим залишається питання особливостей управління вищим військовим навчальним закладом з урахуванням умов сучасних трансформаційних процесів.

Мета статті полягає у визначенні наукових підходів до управління освітнім процесом вищого військового навчального закладу.

Виклад основного матеріалу. Все більш помітним стає залежність розвитку суспільства від якості освіти. Ефективне управління освітнім процесом нерозривно пов'язане зі стійким та успішним розвитком освітньої галузі, іiї динамічністю і потенціалом. Сьогодні в освітніх процесах відбуваються суттєві зміни які зумовлені демократизацією освіти, розширенням автономії навчальних закладів, академічною мобільністю здобувачів освіти. Розширюються інформаційні можливості, збільшується цінність знань, інформації та виникає потреба управління інформаційними ресурсами, зростає роль персоналу, як людського капіталу. Збільшується кількість управлінських альтернатив, що перетворює процес управління навчальним закладом в науку. Водночас управління залишається унікальним мистецтвом роботи з людьми.

У Доповіді ООН про людський розвиток зазначається зокрема, що “освіта збільшує багатство, підвищує цінність та гідність людського життя, найбільшою мірою формує суспільство знань, зміцнює соціальну, культурну та духовну згуртованість людей, зменшує прояви дискримінації та небезпеки, посилює конкурентоспроможність, отже, розглядається як основний засіб розширення можливостей і вибору людини" [5]. Зазначене дає можливість вважати, що проблеми економічного та соціального поступу, реформування сектору національної безпеки та оборони України можуть у значній мірі компенсуватися за рахунок розвитку потенціалу особистості, підвищення якості людського капіталу, успіх якого визначається якістю освіти, тобто ефективним управлінням освітнім процесом. 
Дослідженню філософських та методологічних засад управління освітнім процесом присвячено чимало наукових досліджень українських та закордонних вчених (Дж. Дьюї， В. Кремень， Е. Коротков， М. Нещадим， В. Олійник), однак трансформаційні процеси інформаційного суспільства вимагають постійного перегляду та вдосконалення наукових підходів до управління освітою.

Головною метою управління освітнім процесом закладу вищої освіти залишається підвищення якості освіти. Для системи військової освіти забезпечення якості підготовленості військових фахівців безпосередньо впливає на обороноздатність держави. Досягнення якості освіти пов'язане з суспільноекономічним та науково-технічним розвитком суспільства. Забезпечення необхідної якості освіти вимагає особливої уваги до оновлення освітнього змісту, а також зміни умов, форм та засобів навчання. Науковий підхід до управління освітнім процесом передбачає чітке усвідомлення мети i програмування результатів навчання, він завжди пов'язаний з філософією освіти. Сучасна філософія освіти визначає якісну освіту запорукою розвитку науки, суспільства, економіки та виробництва.

Для ефективного управління освітнім процесом слід враховувати тенденції, що відповідають сучасній філософії освіти. Е. Коротков виокремлює зокрема такі: "усвідомлення освіти, як чинника розвитку культури у всіх іiї проявах, головної умови покращення якості життя людини; освіта здобувається не тільки в межах закладу вищої освіти, а й за його межами; освіта на основі інтеграції всіх способів пізнання людиною світу; розвиток і включення в процес освіти синергетичних уявлень про відкритість світу, цілісності та взаємопов'язаності людини, природи і суспільства; вільне користування інформаційними ресурсами; особистісна спрямованість освітнього процесу; розвиток інформаційної культури та критичного мислення; процес постійного пошуку, зміни і формування нових орієнтирів та цілей; партнерство викладача й здобувача освіти" [6].

Вказані тенденції засвідчують перехід до моделей відкритої освіти, що вимагає принципових змін в організації та управлінні освітнім процесом. При цьому необхідно зважати на те, що йдеться не про повну відмову від форм, методів, структур традиційної освіти, а про цільове еволюційне насичення перспективними елементами нової системи.

В. Олійник вважає, що “розвиток систем відкритої освіти зумовлений такими причинами: прискоренням темпів змін на ринку праці; підвищеною потребою у вищій освіті серед населення та неможливістю іiі задоволення в межах традиційних систем освіти; швидкими темпами розвитку інформаційних i телекомунікаційних технологій; розумінням громадянами того, що інформація основа економічного, соціального, культурного розвитку, а освіта - основа виживання як кожної людини, так і суспільства в цілому; перетворенням освітніх закладів в освітні мережі різних рівнів і різного призначення; перетворенням національних освітніх систем у прибуткові галузі економіки" [7, с. 26].

Ефективність управління ВВНЗ забезпечується науково обгрунтованою i технологічно відпрацьованою системою, що спирається на сукупність підходів до організації управлінської взаємодії. У сучасній теорії управління освітою немає 
єдності в поглядах на порушену проблему: одні дослідники виходять із принципу домінантних чинників i визначають три основних підходи до управління: цільовий, діяльнісний, особистісний [8, с.477], а інші класифікують підходи відповідно до основних концепцій управління (технократичної, людиноцентричної та синтетичної) [9, с. 24-25].

Розглядаючи освітній процес у вищому військовому навчальному закладі, як систему відкритої освіти, у першу чергу, серед наукових підходів до управління освітнім процесом, виокремимо методологію системного підходу. Застосування цього підходу знижує випадковість і стихійність в управлінні. В. Безпалько у своїх роботах визначає педагогічну систему як систему управління педагогічним процесом, яка складається 3 діалектичної суми дидактичного i виховного процесів.

У своєму дослідженні управління освітнім процесом ми розглядаємо 3 позиції цілісності взаємозалежних зв'язків управління, самоврядування i саморегуляції особистості. Системотворчим чинником в освітніх системах виступають цілі. Слід зауважити, що цілі, будучи системотворчим чинником в управлінні, не виникають самі собою, а обумовлені, з одного боку, соціальним замовленням, що формується суспільством, а 3 іншого, - запитами самої особистості як учасника освітнього процесу.

В якості утворювального чинника освітнього процесу виступає також функціональний підхід. У процесі управління цей підхід реалізується в тих, що змінюють один іншого етапів: цілепокладання, аналіз, прогнозування, планування, організація виконання, всебічне забезпечення, контроль, регулювання і корекція.

Дослідивши сутність системного та функціонального підходів до управління освітнім процесом, встановили низку недоліків, а саме: спрямування управлінських зусиль в першу чергу на організаційно-структурні аспекти, на шкоду змісту; переваження режиму усунення недоліків над профілактикою таких; низька орієнтованість на особистість на противагу управлінських процесів.

Подолання цих недоліків вбачаємо в застосуванні методології синергетичного підходу, де основною якісною категорією виступає самоорганізація, що найбільше відповідає системам відкритого типу. Потреба сьогодення така, що кожен заклад вищої освіти має стати соціально-освітньою системою, що самоорганізовується, розвивається на основі власних можливостей, ресурсів середовища i забезпечує умови для самовизначення i саморозвитку суб'єктів освітнього процесу.

3 позиції синергетичного підходу до управління освітнім процесом можливе формування адаптивного освітнього середовища, що враховує людський чинник, характер закладу освіти, в якому реалізується освітня діяльності. Таким чином, управління освітніми системами і процесами на основі синергетичного підходу пов'язано 3 особистісно орієнтованим навчанням, оскільки провідна роль у процесі цього відводиться самоорганізації, саморозвитку, здійснюваних на основі управлінського проектування і консультування. 
Реалізацію управління освітнім процесом необхідно розглядати і через призму діяльнісного підходу, який виступає мотиваційною спрямованістю суб'єкта, що володіє певною метою.

Управлінська діяльність, безперечно, вимагає рефлексії, тому для нас має значення й методологія рефлексивного підходу. У педагогічних джерелах поняття "рефлексія" трактують як звернення назад; роздум, самоспостереження, самопізнання; форму теоретичної діяльності людини, спрямованої на осмислення своїх власних дій і їх наслідків.

Зазвичай, рефлексія виступає у взаємозв'язку з такими чинниками впливу на розвиток особи, при яких усвідомлюється сенс дій, потреба в цілеспрямованій перетворюючій діяльності, бо глибока самосвідомість призводить до самовизначення, самовираження, самоствердження, самореалізації, саморегуляції та ін. Для протікання процесів рефлексії від самосвідомості до саморегуляції потрібні певні механізми - регулятори мислення, комунікації і кооперації. На наш погляд, рефлексивний підхід до управління освітнім процесом має, передусім, забезпечувати створення адаптивного освітнього середовища у процесі взаємодії усіх суб'єктів управління.

Впровадження настанов запропонованих наукових підходів до управління освітнім процесом вбачаємо в реалізації системи принципів. Сьогодні в якості основних принципів управління освітнім процесом називають: науковості, демократизації і гуманізації, системності та цілісності, оптимального поєднання централізації і децентралізації, організації і самоорганізації, об'єктивності і конкретності, оптимальності й ефективності. Нехай запропоновані принципи до певної міри є теоретичним ідеалом, проте, такий ідеал необхідний, оскільки в ньому вбачається значущість теорії управління для освітньої практики.

Зважаючи на складність та багатоаспектність освітнього процесу, враховуючи настанови методологічних підходів, управління освітнім процесом пропонуємо організувати на основі відповідного циклу, що охоплює наступні етапи: цільовий, (де відбувається усвідомлення і визначення мети і завдань освітньої діяльності); мотиваційний, (суб'єкт управління стимулює пізнавальний інтерес здобувачів освіти, що породжує у них потреби і мотиви до активності в освітній та самоосвітній діяльності); змістовний, (визначення освітнього змісту 3 урахуванням цілей навчання, інтересів та здібностей здобувачів освіти; операційний, власне педагогічна взаємодія суб'єктів освітнього процесу через реалізацію відповідних методів, прийомів, форм, засобів); контрольний, (відбувається моніторинг освітнього процесу та якості освіти); рефлексія, (самоаналіз, самооцінка з подальшою корекційною роботою).

Структурно систему управління вищим військовим навчальним закладом, можна представити як єдність діалектично взаємопов'язаних підсистем менеджменту (керівництво, органи управління, вчена рада, загальні збори та ін.) і поведінкової (цінності, місія, напрями розвитку, мотиви та ін.). Складники останньої формують ділову організаційну культуру та $є$ загальними установками, орієнтирами, що визначають напрям до чого прагнути і якими для цього слід бути. Але щоб освітні підрозділи вищого військового навчального закладу 
враховували їх у своїй повсякденній роботі, а не тільки епізодично, проголошені цілі і принципи мають бути локалізовані та подані у вигляді конкретних заходів, які доцільно передбачати у плануванні та здійсненні освітнього процесу. Локалізація та конкретизація цільових настанов покладається на систему менеджменту. Сутність цього процесу полягатиме у виокремленні найкращих освітніх практик, прийняття їх за стандарти освітньої діяльності (при цьому норми стандартів $є$ обов'язковими i визначають мінімальні вимоги як до діяльності так і до якості освіти), формування моделей ідеальних організацій.

Метою функціонування системи управління вищого військового навчального закладу є не лише ефективність освітнього процесу, а й пристосовність до умов і викликів сьогодення, інноваційний розвиток на наукових засадах, натхнення персоналу та суб'єктів освітнього процесу, соціальна відповідальність, що полягає у реалізації соціально значущих, благородних завдань. Керівник вищого військового навчального закладу у такій системі управління - це лідер соціальний архітектор, що забезпечує можливості для співпраці, творчості, інновації. Він вибудовує комунікації, які виключають страх підлеглих перед керівником, а базуються на довірі, стимулюють обмін інформацією, вільне висловлювання думок, заохочує ризик і прийняття на себе відповідальності.

Якість управління освітньою діяльністю вищого військового навчального закладу визначається цілою низкою критеріїв. Одним 3 найважливіших $\epsilon$ професіоналізм управлінців, що виражається в їхній здатності доцільно спрямовувати ресурси на найбільш актуальні, важливі та перспективні напрями розвитку закладу вищої освіти.

Вчені зазначають, що визначальною умовою продуктивності діяльності підлеглих, постійного підвищення їхнього професійного рівня $є$ прагнення до успіху і визнання, зацікавленість у кар'єрному зростанні, заохоченні. Саме тому важливого значення набуває формування в усіх суб'єктів управлінської взаємодії спонукальних мотивів до активної та ефективної діяльності, створення керівником дієвого механізму стимулювання особистісних i професійних досягнень учасників освітнього процесу [10, с. 47]. В даному контексті професіоналізм не зводиться лише до їхньої фахової підготовленості, що $\epsilon$ поверхневим та спрощеним розумінням, а включає володіння спеціалізованими технологіями роботи 3 персоналом, сучасними засобами інформатизації управління, науковою методологією вироблення управлінських рішень, методикою раціонального розподілу ресурсів та часу.

Критерієм якості управління освітнім процесом є також наявність і статус підрозділів у структурі системи управління. Можемо сформулювати низку принципів їх успішної діяльності:

орієнтація діяльності підрозділів управління на освітні цілі навчального закладу, оскільки персонал управління навчального закладу не завжди звіряє свою діяльність 3 цілями освітньої діяльності або тлумачить їх по-своєму, що не сприяє інтеграції діяльності викладачів, здобувачів освіти та керівництва вищого військового навчального закладу; 
залучення науково-педагогічних працівників та здобувачів освіти до вирішення проблем управління освітньою діяльністю;

децентралізація функцій підвищення і контролю якості освітньої діяльності. Контроль здебільшого здійснювати через взаємоконтроль і самодисципліну, на управлінські підрозділи покласти функції моніторингу освітньої діяльності;

запровадження інформаційних технологій в управлінських процесах.

Комплексне застосування цих принципів дозволить задовольняти суспільні вимоги до вищої військової освіти, залучати науково-педагогічних працівників та здобувачів освіти до вдосконалення управлінських процесів, будувати гнучку систему менеджменту здатну бути стійкою до неминучих непередбачуваних змін, вибудовувати майбутнє в якому вищий військовий навчальний заклад зможе стало розвивати свої спроможності.

Висновки. Освіта була i залишається рушієм суспільного розвитку. Досягнення високої якості освіти можливо лише за умови ефективного управління освітнім процесом. Ефективне управління грунтується на основі розуміння та усвідомлення закономірностей та тенденцій розвитку освіти в умовах суспільних трансформаційних процесів.

Оформлення нової філософії освіти, що визначає іiі, як систему відкритого типу, з необхідністю спричинило перехід до нової управлінської парадигми, яка грунтується на застосуванні множини альтернативних підходів до управління освітніми системами і процесами. На даний час управління освітнім процесом у закладах вищої освіти здійснюється на основі методології системного, функціонального, синергетичного, діяльнісного, рефлексивного й інших наукових підходів.

Система управління вищим військовим навчальним закладом формує ділову організаційну культуру сутність якої має полягати у виокремленні найкращих освітніх практик, прийнятті їх за стандарти освітньої діяльності. Завдання менеджменту полягає у визначенні соціально значущих цілей освітньої діяльності, професіоналізації науково-педагогічних працівників шляхом розвитку їхного особистісного потенціалу, забезпеченні внутрішніх та зовнішніх комунікацій та розподілі ресурсів відповідно до освітніх пріоритетів.

Напрями подальших досліджень. Подальші дослідження полягатимуть у розробленні та експериментальній перевірці методів та механізмів управління освітніми процесами на основі визначених теоретико-методологічних положень.

\section{ЛІТЕРАТУРА}

1. Кушнір I. I. Сучасний погляд на освітній менеджмент. Науковий вісник Мукачівського державного університету. Серія “Педагогіка та психологія”. Мукачево: МДУ, 2020. Вип. 1(11). C. 28-30.

2. Алімпієв А. М., Толок І. В., Литвиненко М. І. Моніторинг якості підготовки військових фахівців у вищих військових навчальних закладах та військових навчальних підрозділах вищих навчальних закладів Збройних Сил України : наук.-метод. Посіб. Та ін.; Харків : ХНУПС, 2017. 244 с.

3. Осьодло В., Ворона Т., Пелих А. Вища освіта України у контексті інформаційного суспільства. Збірник наукових праць “Військова освіта” Наџіонального університету оборони України імені Івана Черняховського. Київ : НУОУ, 2018. № 2(38). С. 183-191. 
4. Аналітична записка "Глобальні тренди розвитку науки i технологій: нові виклики i можливості”. Національний інститут стратегічних досліджень. 25.05.2020. Київ, 2020. 5 с.

5. United Nations Development Programme: Human Development Reports. 2018, p.6. URL: http://hdr.undp.org/en/2018-update

6. Коротков Э. М. Управление качеством образования: Учебное пособие для вузов. Москва : Академический Проект : Мир, 2006. 320 с.

7. Олійник В. В. Відкрита післядипломна педагогічна освіта і дистанційне навчання в запитаннях і відповідях : наук.-метод. посіб. НАПН України, Ун-т менедж. освіти. Київ: "A.C.K" 2013. 312 c.

8. Кремень В. Г., Пазиніч С. М., Пономарьов О. С. Філософія управління: підруч. [вид. 2-е, доп. І перероб.]. Харків : НТУ “ХПІ”, 2008. 524 с.

9. Немченко С. Г., Голік О. Б., Кривильова О. А., Лебідь О. В. Управління навчальним закладом : підруч. Донецьк : ЛАНДОН-ХХІ, 2012. 516 с.

10. Осьодло В. І., Вітченко А. О. Розвиток системи вищої військової освіти України в контексті сучасних трансформаційних змін. Наука $i$ оборона: науково-теоретичний та науково-практичний журнал. Київ, 2019. №2. С 44-50.

\section{REFERENCES}

1. Kushnir, I.I. (2020). Suchasnyi pohliad na osvitnii menedzhment [A modern view of educational management] Naukovyi visnyk Mukachivskoho derzhavnoho universytetu. Seriia "Pedahohika ta psykholohiia". Mukachevo : MDU, Vyp. 1(11). S. 28-30. (in Ukrainian).

2. Alimpiiev, A.M., Tolok, I.V., Lytvynenko, M.I. (2017). Monitorynh yakosti pidhotovky viiskovykh fakhivtsiv u vyshchykh viiskovykh navchalnykh zakladakh ta viiskovykh navchalnykh pidrozdilakh vyshchykh navchalnykh zakladiv Zbroinykh Syl Ukrainy [Monitoring the quality of training of military specialists in higher military educational institutions and military educational subdivisions of higher educational institutions of the Armed Forces of Ukraine]: nauk.-metod. posib. ta in.; Kharkiv : KhNUPS. 244 s. (in Ukrainian).

3. Osodlo, V., Vorona, T., Pelykh, A. (2018). Vyshcha osvita Ukrainy u konteksti informatsiinoho suspilstva [Higher education in Ukraine in the context of the information society]. Zbirnyk naukovykh prats "Viiskova osvita" Natsionalnoho universytetu oborony Ukrainy imeni Ivana Cherniakhovskoho. Kyiv : NUOU. № 2(38). S. 183-191. (in Ukrainian).

4. Analitychna zapyska "Hlobalni trendy rozvytku nauky i tekhnolohii: novi vyklyky i mozhlyvosti" [Analytical note "Global trends in science and technology: new challenges and opportunities"]. Natsionalnyi instytut stratehichnykh doslidzhen. 25.05.2020. Kyiv, (2020). 5 s. (in Ukrainian).

5. United Nations Development Programme: Human Development Reports. 2018, p.6. URL: http://hdr.undp.org/en/2018-update (in English).

6. Korotkov, Je.M. (2006). Upravlenie kachestvom obrazovanija [Education quality management]: Uchebnoe posobie dlja vuzov. Moskva: Akademicheskij Proekt : Mir. 320 s. (in Russian).

7. Oliinyk, V.V. (2013). Vidkryta pisliadyplomna pedahohichna osvita i dystantsiine navchannia $\mathrm{v}$ zapytanniakh $\mathrm{i}$ vidpovidiakh [On the basis of a diploma on pedagogical education and remote sensing in power supplies and information] : nauk.-metod. posib. NAPN Ukrainy, Un-t menedzh. osvity. Kyiv : "A.S.K” 312 s. (in Ukrainian).

8. Kremen, V.H., Pazynich, S.M., Ponomarov, O.S. (2008). Filosofiia upravlinnia [Philosophy of management] : pidruch. [vyd. 2-e, dop. i pererob.]. Kharkiv : NTU "KhPI". 524 s. (in Ukrainian).

9. Nemchenko, S.H., Holik, O.B., Kryvylova, O.A., Lebid, O.V. (2012). Upravlinnia navchalnym zakladom [Management of the principal mortgage] : pidruch. Donetsk : LANDON-XXI. 516 s. (in Ukrainian).

10. Osodlo, V.I., Vitchenko, A.O. (2019). Rozvytok systemy vyshchoi viiskovoi osvity Ukrainy $\mathrm{v}$ konteksti suchasnykh transformatsiinykh zmin [Development of the system of vital news of Ukraine 
in the context of the current transformations]. Nauka i oborona : naukovo-teoretychnyi ta naukovopraktychnyi zhurnal. Kyiv. №2. S 44-50. (in Ukrainian).

\section{PEЗЮМЕ}

Василий Осьодло, доктор психологических наук, профессор Национальный университет обороны Украины имени Ивана Черняховского

Олег Рыбчук, доктор философии Национальный университет обороны Украины имени Ивана Черняховского

Татьяна Ворона,

Национальный университет обороны Украины имени Ивана Черняховского

\section{Научные подходы к управлению образовательным процессом высших военных учебных заведений}

Статья посвящена исследованию научных подходов к управлению образовательным прочессом в высших военных учебных заведениях. На основе анализа современных научных исследований определены закономерности и тенденщии развития образования в условиях трансформационных прочессов. Обоснованно философские и методологические детерминанты новой образовательной парадигмы, согласно которой система управления высшим военным учебным заведением, как система открытого типа, на основе выделения лучших образовательных практик и принятия их за стандарты образовательной деятельности формирует новую деловую организационную культуру. Обоснованно задачи современного образовательного менеджмента высших военных учебных заведений, они заключаются в определении социально значимых целей образовательной деятельности, профессионализачии научно-педагогических работников путем развития их личностного потенциила, обеспечении внутренних и внешних коммуникащий и распределении ресурсов $в$ соответствии с образовательными приоритетами.

Ключевые слова: управление; образование; развитие; учебное заведение; качество.

\section{SUMMARY}

Vasyl Osyodlo,

Doctor of Psychological Sciences, Professor

National Defence University of Ukraine named after Ivan Cherniakhovskyi Oleh Rybchuk, Doctor of Philosophy

National Defence University of Ukraine named after Ivan Cherniakhovskyi

Tatiana Vorona,

National Defence University of Ukraine named after Ivan Cherniakhovskyi

\section{Scientific Approaches to Educational Process Management in Higher Military Educational Institutions}

Introduction: The article deals with research of scientific approaches to management of educational process in higher military educational institutions. The peculiarities and tendencies of 
educational process development under transformational conditions were defined based on the results of modern scientific researches.

The purpose is to define scientific approaches to educational process of higher military educational institutions management.

Results: The philosophical and methodological determinants of a new educational paradigm were justified. According to these, the management system of higher military educational institution is a system of an open type, based on the best educational practices and its acceptation as standards of educational activity helps to form a new organizational culture.

Originality: due to results of research it was revealed, that the modern education is a system of an open type. According to the necessity, it leads to shift to the new paradigm, which is based on usage of multiple alternative approaches to educational systems and process management. Currently, educational process management in the institutions of higher education is provided on the basis of systemic, functional, synergetic, active, reflexive and other scientific approaches' methodology.

Conclusion: The task of modern educational management in the higher military educational institutions is to define socially important aims of educational activity, professionalization of scientific and pedagogical workers on the basis of their personal potential development, providing internal and external communication and distribution of resources due to its educational priorities.

Key words: management; education; development; educational institution; quality. 